OK129

- T298

1917

Taylor, Norman

Flora of the vicinity of New York. 


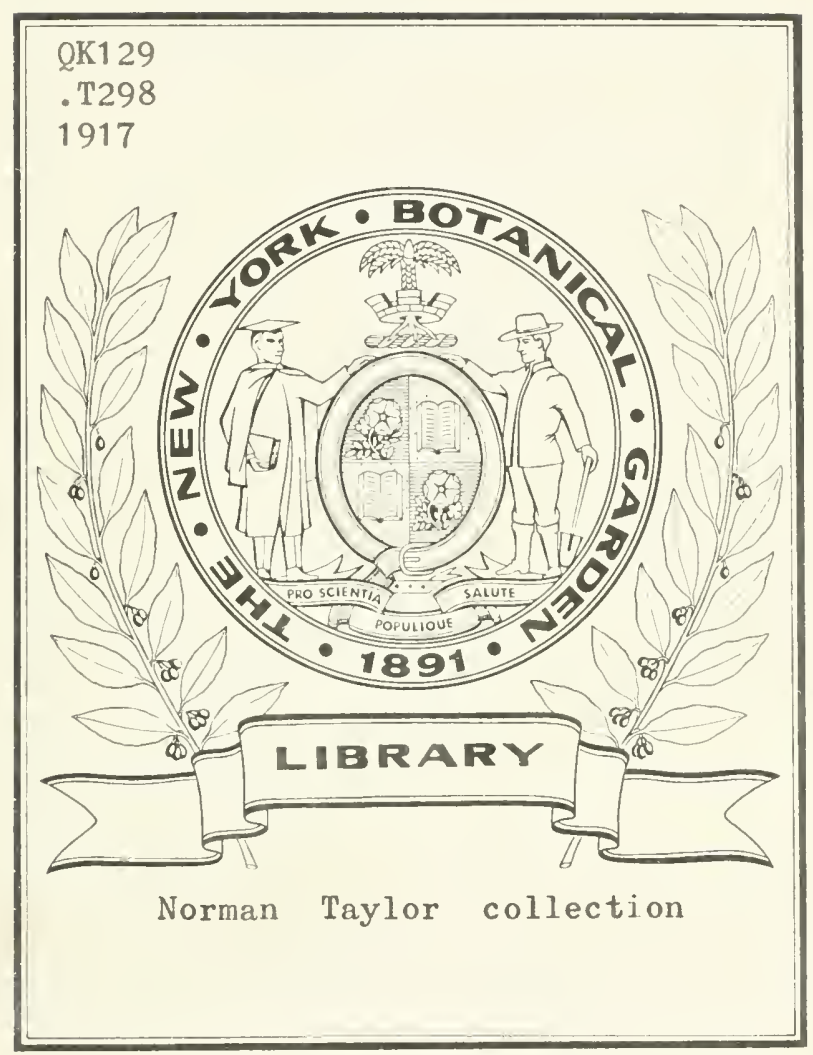




THE BROOKLYN INSTITUTE OF ARTS AND SCIENCES

BROOKLYN BOTANIC GARDEN

\title{
CONTRIBUTIONS
}

No. 16

\section{FLORA OF THE VICINITY OF NEW YORK}

\author{
BY NORMAN TAYLOR
}

BROOKLYN, N. Y.

I9I7

Reprinted, without change of paging, from THE SCIENTIFIC MONTHLY 4: 548-553. June, I9I6. 



\section{FLORA OF THE VICINITY OF NEW YORK}

\section{BY NORMAN TAYLOR}

BROOKLTN BOTANIC GARDEN

$\mathrm{I}^{\mathrm{N}}$ N 1749-1751 Cadwallader Colden, lieutenant-governor of New York and correspondent of Linnæus, published the first flora of New York and ricinity. It was a list of the plants as observed by himself and his daughter Jane Colden, growing near their home in what is still called "Coldenham," Orange Co. Written by a man who wrote to Gronorius that "botany is an amusement which may be made greater to the Ladies who are often at a loss to fill up their time," it well reflects the attitude of his period. As a historical record the list is valuable. As a forecast of the modern position of botany or women, his remarks are commended to botanists and to those feminists who find it difficult to "fill up their time."

Not until 1819 was there another list of this importance, when John Torrey published his "Catalogue of Plants growing Spontaneously within thirty miles of the City of New York." This was a book of 102 pages and listed hundreds of species and varieties, some of which are now rare or extinct near the city. To touch only the high spots of a long historical record, mention should be made of Leggett's " Revised catalogue of the plants, native and naturalized, within thirty-three miles of New York" (18\%-1874) and the "Preliminary Catalogue of Anthophyta and Pteridophyta" reported as growing spontaneously within one hundred miles of New York City by Britton, Stearns and Poggenburg (1888). Some of these lists contained notes on the distribution of the species, but in most cases only lists of plant names were possible. The outstanding character of them all, as in the beginnings of most science, was that they were chiefly records of facts. They were the culmination of our forefathers' study of the local flora, arranged in orderly fashion, which at that time was all that could be done.

It is impossible to talk about the vegetation of New York without knowing very definitely what are the units of that vegetation, and it is the chief legacy of this older generation of New York botanists, that they have handed down to us so complete and so accurate a record of those units, as they knew them. There were, of course, hosts of minor efforts covering the region near the city, or parts of it, about which nothing can be said here, except that like the more important works their object was simply to record the facts. It should not, however, be implied that these workers lacked a larger vision which should seek to explain or correlate their patiently acquired facts. For we find in July, 18\%0, a forecast of what they were striving for, when in 
the Bulletin of the Torrey Botanical Club there appeared in an account of the floral regions of that area, the statement that

Any rational catalogue of our flora should distinguish what plants aro absent from or peculiar to each natural region and should contain such information in reference to soil, climate, etc., as may help to elucidate the distribution.

Among purely local botanists, this was, I think, the first statement implying causation that had appeared. Gray, Torrey and Hooker had all written extensively of the flora of North America, and some of them, at any rate, had written on the larger problems of the origin and distribution of the North American flora. For the region about New York, with its variety of conditions, there seems to have been no opportunity until quite recently to attempt to fulfil the hope of the writer in $18 \% 0$ who is quoted above.

Recent studies of the flora show that there are about 2,600 different species of flowering plants and ferns known to grow within, roughly, 100 miles of the City. Of these 85 are ferns and their allies, 23 are conifers and the balance is made up of our ordinary flowering plants. Of the total flora some 613 species have been introduced from outside the area, by man or otherwise, leaving slightly more than 2,000 species of native plants in the region within one hundred miles of the City. ${ }^{1}$

It is a matter of common observation that these plants are not generally distributed throughout the region. In traveling from the Catskills to Cape May, the northern and southern limits of the area studied, we see a variety of plants found in one or the other of these widely separated localities, but not in both of them. Many species find their outposts of distribution near New York. Some appear to have come from the North or South, a few from the West, others are apparently endemic in the area, and this great quantity of forms, the apparent chaos of it all, raises many questions. What is the real composition of our flora, whence derived, and above all how did it reach its present luxuriance and beauty? The attempt to answer these questions necessitates a review of the causes that have influenced the origin and distribution of our native flora.

For all practical purposes the agencies affecting the distribution of our native plants may be divided into edaphic and climatic ones. Under the first must be considered all questions of the relation of the vegetation to the soil and available water supply; or more simply stated the geological factors of distribution; under the second the relation of the flora to climate must be the chief concern.

From the point of view of plant distribution the last geological phenomenon is the most important, as the continental glacier the fringe of which stretched through Long Island, Staten Island, northern New Jersey and Pennsylvania, had a profound influence on the migration

1 Mem. N. T. Botanical Garden, 5, 1-683, 1915. 
of the flora existing at that time. It is obvious that whatever the effects of geological eras before the ice age may have been on the then existing flora, this great ice sheet must have obliterated all the vegetation in the region which it covered. All the region north of the southern edge of the continental ice sheet must have started with regetatively a clean slate, as it were, when the ice receded. What was the edge of the ice sheet is now marked by an irregular range of hills which stretch from Montauk Point to northeastern Pennsylvania. These morainal hills mark the present southerly distribution of many of our species of plants. Over 8 per cent. of our native flora has never been found south of these morainal hills, notably the red pine (Pinus resinosa), the balsam (Abies balsamea), yellow birch (Betula lutea) and Quercus borealis among the trees; Ribes glandulosum, the shrubby cinquefoil (Dasiphora fruticosa), many thorns, the Rhodora and Kalmia glauca among the shrubs, besides scores of herbaceous plants.

This glaciated part of the range is characterized, too, by the large percentage of hardwood deciduous trees, and by the great number of introduced plants that are found there. Most of our European weeds flourish in the much-cultivated region north of the moraine.

The unglaciated part of the area is mostly occupied by the coastal plain which, on the whole, is characterized by the long sandy or gravelly stretches that are found on southern Iong Island and New Jersey. All of the region is geologically the most recent in the area, the surface being largely made up of Tertiary and Cretaceous deposits in New Jersey and over-wash material from the glacier on Long Island. From the standpoint of the botanist the chief thing of interest about the coastal plain is the pine-barren region of New Jersey. This region is so unusual that the ordinary traveler is at once struck with the difference between these sandy stretches of pine-tree vegetation and the richer flora further north.

It has been shown ${ }^{2}$ that the pine-barrens occupy almost exclusively the Beacon Hill formation, in New Jersey, which has been uninterruptedly out of the water since upper Miocene time, and has been several times partly, or wholly, surrounded by sea water. Because of its continual emergence it is the oldest region in our area that can have been continuously covered with vegetation. For the region surrounding the barrens was subject several times to the invasion of sea water, and as we have seen the glaciated area, geologically much more ancient, must have been fairly scraped clear of vegetation by the ice. In other words, the New Jersey pine-barrens exist exclusively on the Beacon Hill formation, an area isolated by geological processes and maintaining a relict flora, which is much older in permanency of occupation than any of the rest of the flora near New York.

Ancestrally our local flora must have consisted of purely American

2 Torreya, 12, 229-242, 1912. 
plants, many of which were of southern affinities. Many southern species still reach their extreme northern outposts of distribution in this region. Most of the southern species are found on the coastal plain, but a few have spread north and west of it. At the present time over 13 per cent. of our local plants reach their northern limits within one hundred miles of the City of New York. Many other southern plants, also, range only slightly to the north of us.

About 8 per cent. of the native vegetation, also, consists of northern species that reach their southern limits within the local flora area, and many more are found to the south of us in the mountains. The great range of hills, stretching northeast-southwest from the Berkshires through the Catskills and the Highlands of the Hudson in New York, the Kittatinny in New Jersey and to the Blue Mountains of eastern Pennsylvania, serve literally as a broad highway down which a host of northern species are scattered, and to the seaward of which certain kinds have never been known to go. That other great group of species that creeps, almost insidiously, from the south, scems perforce to have been huddled between the mountains and the sea. The transition between these northern and southern elements of our flora is, of course, nothing like so sharp as the geological regions they generally occupy would seem to indicate. Many sporadic marauders have spread from both camps, apparently far out of their element. Sometimes these lonely outposts survive the competition of the new environment; that is notably the case of the hemlock in southern New Jersey, far from its usual rocky hillsides, and of the coast white-cedar (Chamcecyparis) which flourishes in the coastal-plain bogs, and maintains a rather splendid isolation at Greenwood Lake, in northern New Jersey. Scores of these cases could be cited illustrating the main lines of the distribution of our flora by occasional aggressive exceptions to it. Such sporadic occurrences form one of the most fascinating chapters in the history of our native flora, for are they not militant outposts of a mighty horde of conservatives? Sometimes they perish miserably as the little twin-flower has long since done on southern Long Island, miles from its mountain home. Of the number of such tragedies no man can even guess, still less speculate as to their causes, but speculation could weave about such occurrences, and they are very numerous even in such a limited area as this, a story the significance of which has breath-taking possibilities. For with these outcasts, whether living or dead, is bound up a whole history of changing climates and shifting levels of our continent-mighty forces which have scattered here and there mute little relics of their sport.

The real potency of these geological forces, or historical factors of distribution, is so great and its appeal to the imagination can be made so alluring, that we are in danger of attributing the general complexion of our vegetation almost solely to them. Nothing could give us such a 
one-sided, wholly erroneous conception. Our present climate, particularly temperature, seems quite certainly to be the controlling factor in the present distribution of many of our native species. As to rainfall and the winds, their variation seems almost negligible in so small a region, but temperature is a much more serious matter. There seems to be a rather well-defined temperature barrier through which some plants have never been known to go.

For a variety of reasons that need not detain us here, the particular criterion of temperature response that has been studied in connection with our native flora is that of the length of the growing season. This is determined by figuring the number of frostless days in different parts of the area. The accompanying map illustrates the method better than a page of explanation could do. The arbitrarily drawn black line through the map indicates the dividing line between colder and warmer regions of our area. It marks, with occasional exceptions, the southerly limit in our area of many cold-country plants. North of it occur most of our higher elevations where the mountain species are found. The difference of three months in the growing season as between the Catskills and Cape May is very nearly as impressive as the conspicuously different vegetation of these widely separated localities.

The mental convenience of considering separately the effects of

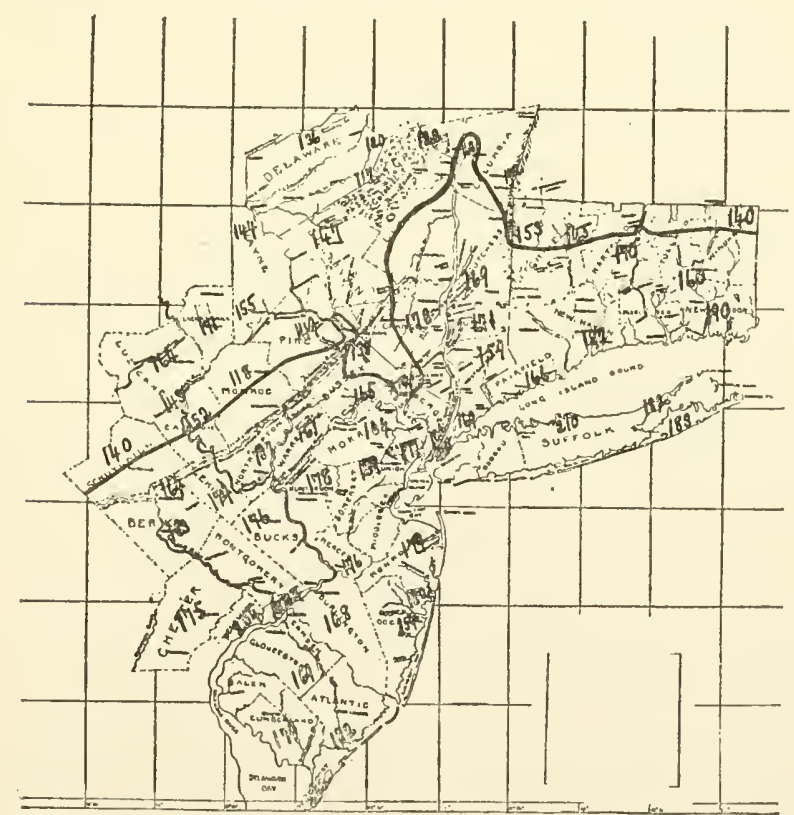

Fig. 1. Map Illustrating the length of the Growing Season within 100 MILES of NEw YoRk. The figures represent the number of days between the last killing frost in spring and the first of autumn. The dark line separates the warmer from the colder parts of the area, and indicates generaliy speaking a climatic barrier through which certain of our native plants have never been known to go. 
geology and climate on the distribution of our flora must not blind us to the fact that these agencies do not work independently. The interaction of these, the further complication of the personal "aggressiveness" of certain species, if that term can be applied to plants, and many other minor factors, make the problem most complex. In any particular case it may be practically impossible to say whether a given plant exhibits response to climatic or geological factors, or to both, least of all as to what possible combination of both. All that can be done is to set down the facts of distribution, both with relation to geology and to climate, and to estimate the relative proportion of the potency of each. That such a study must spell a large measure of failure should deter no one. For by it is acquired an outlook upon the vegetation of an area that no preparation of lists of species can possibly confer. Upon such a conception a flora ceases to be a catalogue, mere scaffolding for the structure that is to follow, as necessary and as uninteresting as the telephone directory. Upon such a conception a flora need not concern itself with the latest hair-splitting refinements of the ever-present species-monger. All of these things are subsidiary to the larger problems that come from what may be called a causative study of a flora. By it each of our native plants takes on an added interest, to many there may be attached a history that fascinates the most unimaginative, to the whole is given a new impetus and a broader vision, which can make of any landscape something very like a dramatic spectacle.

Troublesome persons with a practical bent will want to know of what use such a study of any flora can be, least of all of the region near New York. Apart from its consideration as a great out-door experiment or laboratory where all sorts of principles of distribution can be studied at first hand, there are purely local problems that are commercially important. The draining and reclamation of our great saltmarsh areas on Long Island and in New Jersey, which is bound up with mosquito extermination, offers an attractive field of work where such knowledge will have a direct bearing. The profitable utilization of the southern part of Long Island, now a dreary waste of scrub-oak and pitch-pine, and of the pine-barrens of New Jersey, must involve the utilization of such studies to insure a full measure of success. The timber and crop possibilities of some parts of the area are well indicated by the wild vegetation, and the vegetational history of many parts of the region must serve as a clue to its most profitable future utilization. Thus a study of a flora from the standpoint of its fitness for its environment, and the intimately related study of the environment as fitted to the existing flora, must bulk large in any rational scheme for the agricultural or horticultural development of the region near the city, many parts of which are still wholly undeveloped, or, worse still, have been recklessly exploited. 
、 




\section{THE BROOKLYN INSTITUTE OF ARTS AND SCIENCES \\ BROOKLYN BOTANIC GARDEN}

\section{CONTRIBUTIONS}

This series consists of papers originally published in botanical or other periodicals, re-issued as "separates" without change of paging, and numbered consecutively. It includes occasional papers, as well as those embodying the results of research done at the Brooklyn Botanic Garden, or by members of its staff and students. Twenty-five numbers constitute one volume. Offered in exchange, or for sale at 25 cents a number; $\$ 5.00$ a volume.

\section{PRECEDING NUMBERS}

I. The educational woric of botanic gardens. I3 pages. I9II.

2. The purpose of an introductory course of botany. 8 pages. I9II.

3. Cryptomeric inheritance in Onagra. II pages, 2 figures, 2 plates. I9I I.

4. On the origin and present distribution of the pine-barrens of New Jersey. 15 pages, 2 figures. $1 ; 12$.

5. Ingrowing sprouts of Solanum tuberosum. Io pages, 6 figures, I plate. I9I2.

6. Intermingling of perennial sporophyitic and gametophytic generations in Puccinua Podophyiii, P. obtegens and Uromyces Glycyrrhizae. I5 pages, I plate. I9I3.

7. Studies of teratological then.mena in their relation to evolution and the problems of heredity. I. A stuly of certain floral abnsmalities in Nicotiana and their bearing on theories of dominance. 14 pages, 4 figures. I9I4.

8. Some observations on the formation of the capillitium and the development of Physarella mirabilis Peck and Stemonitis fusca Roth. I5 pages, I double plate. I914.

9. The growth forms of the flora of New York and vicinity. 9 pages. I915.

Io. Inheritance stulies in Pisum. I. Inheritance of cotyledon color. I9 pages, 4 tables. I9I6.

II. Studies of teratological phenomena in their relation to evolution and the prohiems of heredity. II. The nature, causes, distribution, and inheritance of fusciation with special reference to its occurrence in Nicotiona. 70 to 80 pages, 32 tables, 28 figures. I9I6.

12. Endemism in the flora of the vicinity of Nerw York. I0 pages. I9I6.

13. The origin of new varieties of Nephrolepis by orthogenetic saltation. I. Progressive variations. 28 pages, 6 plates. 1916.

14. A white-cedar swamp at Merrick, Long Island, and its significance. Io pages, 5 plates. 1916.

15. Present stitus of the problem of the effect of radium rays on plant life. 8 pages. 1916. 
aylor Norman/Flora of the vicinity of 


